\title{
ЛІТАРАТУРАЗНАั̆СТВА
}

Siarhiej Kawalou

Lublin

\section{Zapomniany poeta polsko-białoruski: twórczość Jana Kozakowicza}

Zważywszy na ilość utworów opublikowanych w wydaniach wileńskich pod koniec XVI - na początku XVII w. za najbardziej aktywnego wśród ówczesnych poetów Wielkiego Księstwa Litewskiego należy uznać Jana Kozakowicza. O popularności Kozakowicza wśród współczesnych świadczy również obecność jego wierszy dedykacyjnych w książkach innych poetów (Mikołaja Reja, Andrzeja Rymszy, Jana Radwana) oraz pojawienie się epigramatu na samego pisarza w książce Marcina Łaszcza Okulary (Wilno 1594).

To, że Jana Kozakowicza przyszłe pokolenia darzyły znacznie mniejszą uwagą, tłumaczy się nie tylko okrucieństwem czasu, lecz także niewysokim poziomem artystycznym utworów poety. Nie znajdziemy nazwiska Kozakowicza ani w polskim Nowym Korbucie, ani w Polskim stowniku biograficznym, ani w białoruskim słowniku biobibliograficznym Беларускія пісьменнікі. Od czasu do czasu nadmienia się twórczość pisarza w pracach badaczy polskich, litewskich i białoruskich (Wacława Aleksandra Maciejowskiego, Alojzego Sajkowskiego, Zofii Florczak, Marii Barbary Topolskiej, Aleksandra Anuszkina, Dariusa Kuolisa, Jurija Łabyncewa, Iwana Sawierczanki i in.), przeważnie jednak z pobłażliwym komentarzem typu: „kiepskie wiersze" 1 , utwory „pośredniego wierszopisarza" 2 i in.

\footnotetext{
1 W. Maciejowski, Piśmiennictwo polskie od czasów najdawniejszych aż do roku 1830, Warszawa 1852, t. 3, s. 377.

2 Z. Florczak, Udział regionów w ksztaltowaniu się piśmiennictwa polskiego XVI wieku. Studium z zakresu socjologii pisarstwa, Wrocław 1967, s. 193.
} 
Jan Kozakowicz nie był wybrańcem muz: tylko ich skromnym sługą, lecz bez jego dorobku obraz polskojęzycznej poezji Białorusi i Litwy XVI - początku XVII w. nie byłby pełnym: biografia twórcza Kozakowicza jest jaskrawą ilustracją ówczesnego procesu literackiego, jej rekonstrukcja daje możliwość zrozumienia tego, które z gatunków poetyckich były najbardziej popularne w środowisku ówczesnej szlachty.

Nie zachowały się żadne fakty z biografii Kozakowicza, nie są znane miejsce i data urodzenia poety. Jednak można stwierdzić niemal jednoznacznie, że był on obywatelem Wielkiego Księstwa Litewskiego, ponieważ do swojego nazwiska dodawał przydomek „Litwin”. Na ziemiach Księstwa było wiele zaścianków o nazwie „Kozaki”: niedaleko Trok, pod Mińskiem, na Wilenszczyźnie ${ }^{3}$. Jan Kozakowicz należał zapewne do tego samego pokolenia, co jego przyjaciele Andrzej Rymsza i Jan Radwan: do pokolenia urodzonych w 50. latach XVI w. Pochodził z drobnej szlachty, był kalwinem według wyznania, związany z dworem Radziwiłłów birżańskich. Wiersze pisał po polsku i po łacinie, parał się tłumaczeniami na język polski.

Pierwszy znany nam utwór Kozakowicza podpisany kryptonimem „J. K.” został umieszczony w wydanej przez Daniela Łęczyckiego książce Andrzeja Rymszy Dziesięćroczna powieść wojennych spraw... Krysztofa Radziwiła... (Wilno 1585). Jest to wiersz dedykacyjny o wymownej nazwie: Do autora dobry przyjaciel. Kozakowicz pisze o swoim przyjacielu jak o znakomitym poecie: „jużeś niebo osławił nieraz swoim zdaniem. I ziemiś pięknie służył książek swych wydaniem" ${ }^{4}$. Rymsza przed Dziesiećroczna powieścia opublikował zaledwie jedną skromną książeczkę: Chronologia... (Ostrog 1581). Tak więc Kozakowicz albo wyolbrzymiał zasługi swojego przyjaciela, albo lepiej od dzisiejszych bibliografów znał jego twórczość. Nie mniej jednak czytał wydaną w języku starobiałoruskim Chronologie, o czym świadczy krótkie jej streszczenie przedstawione w wierszu Do autora dobry przyjaciel.

Obok wiersza Kozakowicza w Dziesięćrocznej powieści znalazł się nieduży łaciński epigramat Jana Radwana. Po trzech latach utwory tych poetów znów pojawiają się pod jedną okładką: w książce Radwana Radivilias sive de vita et rebus... Nikolai Radivili (Wilno 1588), pamięci zmarłego w $1584 \mathrm{r}$. wojewody wileńskiego, hetmana wielkiego litewskiego Mikołaja Radziwiłła Rudego. Wszystkie utwory w tej książce, poza wierszami Kozakowicza oraz

\footnotetext{
3 Stownik geograficzny Królestwa Polskiego, Warszawa 1883, t. 3, s. 535.

4 A. Rymsza, Dziesięćroczna powieść wojennych spraw..., „Archiwum Literackie”, Wrocław i in., 1972, t. XVI, s. 136.
} 
anonimowego poematu Stawy na szczessliwe zwycięstwo... Mikołaia Radziwiła... pod Kiesia... pisane były w języku łacińskim: prozatorskie dedykacje Jana Abramowicza, Andrzeja Wolana, Jana Ruckiego, wiersze oraz epicki poemat Jana Radwana. Można zatem przypuszczać, że książka była przeznaczona nie tylko dla czytelników w kraju, ale też za granicą, aby rozpowszechnić sławę Mikołaja Radziwiłła po całej Europie. Zastanawiającym jest fakt, że Kozakowicz, który jednakowo dobrze znał i łacinę, i język polski wybrał tym razem ten ostatni.

Jan Kozakowicz umieścił w tomiku Radivilias... trzy wierszowane dedykacje młodym Radziwiłłom: Jerzemu, Januszowi i Krzysztofowi, podpisując się pod ostatnim z tych wierszy: „Jan Kozak Litwin”. W owym „tryptychu" przeplatają sie motywy poezji funeralnej, prefacyjnej, dedykacyjnej oraz heraldycznej, co jest cechą charakterystyczną twórczości Kozakowicza, a także całej ówczesnej poezji Wielkiego Księstwa Litewskiego. Wiersze zamieszczono w książce dla uczczenia osoby zmarłej, dlatego rzeczą naturalną jest wspomnienie o Śmierci, która bezlitośnie niszczy wszystko na ziemi (motywy funeralne). Utworem centralnym w tomie jest poemat tytułowy Radwana, i Kozakowicz wychwala przed czytelnikami ,złote pióro wychowanka Padwy" (cel prefacyjny). Wiersze zadedykowane były wnukom Radziwiłła Rudego. W nich poeta nawołuje młodych magnatów, aby byli godnymi sławy przodków, aby pomnażali ją nowymi wielkimi czynami (funkcja dedykacyjna). Dziedziczność sławy rodu jest motywem przewodnim poezji heraldycznej (a także epickiej), jako przesłanie został on wypowiedziany w znanym epigramacie Andrzeja Rymszy na herb Lwa Sapiehy: „Подаваите жъ потомъкомъ, што маете зъ предъковъ!" 5.

Warto zaznaczyć, iż podobne tradycyjne zawołania nabierają u Kozakowicza wyraźnego zabarwienia patriotycznego, jak na przykład w zwrocie do Janusza Radziwiłła:
...Radziwił Radziwiłów świętych drog nie miiay.
Tak długowieczna swemu domowi cześć wzniesiesz,
Kiedy cnota oyczysta potomkom zaszwieciesz.
Day Boże, byś się w sławie tey rozkochał z duszę,
Jeszczeby Litwa miała swoie Kurciusze ${ }^{6}$.

W tryptyku dedykacyjnym Jana Kozakowicza są obecne najbardziej popularne w ówczesnej poezji postacie: Śmierć, Cnota, Sława, przy czym

\footnotetext{
5 Статут Великого Князтва Литовского.., Вильна 1588.

6 J. Radvanas, Radivilias sive de vita et rebus... Nikolai Radivili, Vilnae 1588.
} 
Sława jest postacią centralną (samo słowo „sława” powtarza się dziewięć razy). Na podstawie tego można przypuszczać, iż poemat Stawy na szczęśliwe zwycięstwo... Mikołaia Radziwiła... pod Kiesia..., zamieszczony w książce Radivilias... również jest pióra Jana Kozakowicza. Owe przypuszczenie potwierdza się oprócz tego podobieństwem stylu obydwu utworów oraz przedstawionym w nich ogólnym odczuciem „litwińskiego” patriotyzmu. Napisany w imieniu personifikowanej Sławy wiersz jest typowym przykładem „epinicium”, znanego z czasów starożytności oraz popularnego w epoce renesansu gatunku (greck. - epinikion, łac. - epinicium, carmen triumphale). Niektórzy uczeni za autora Stawy uważają Andrzeja Sapiehę ${ }^{7}$, na co ma wskazywać podtytuł utworu: „Przez porucznika swego Pana Andrzeia Sapehę, woiewodzica Nowogrodzkiego". Jednak w rzeczywistości Andrzej Sapieha nie był autorem wiersza, tylko jednym z głównych bohaterów utworu, „autorem” zwycięstwa nad wojskiem moskiewskim 21 października $1578 \mathrm{r}$. pod miastem Kieś:

Wszystko ślachetnym na łup Rycerzom zostało, Ktorych sie wielkie męstwo w ten czas okazało. Gdy cny Iendrzej Sapieha, twoy Porucznik śmiały, Ktorego przodkow sprawy swoich nie wydały, Gdy z wielka sława Moskwe przed laty biiali, Lecz ich zacnym przykładem iak oni działali: Przewiodszy swe fortelnie przez głębokie brody, Uszykował na uffy bez trwogi y szkody ${ }^{8}$.

Wiersz w tomie Andrzeja Rymszy oraz cztery wiersze w książce Jana Radwana stanowią skromny dorobek twórczy Jana Kozakowicza w 80. latach XVI w. Możliwie, że niektóre wcześniejsze utwory poety nie zachowały się do naszych czasów i nie są nam znane, lecz mało prawdopodobne jest to, żeby już wtedy istniały osobne wydania jego utworów.

W ciągu kolejnego dziesięciolecia Kozakowicz równie chętnie umieszcza swoje wiersze w tomach różnych autorów: robi to, zapewne, na zamówienie fundatorów (Krzysztofa Zienowicza, Mikołaja Zienowicza, Mikołaja Naruszewicza, Michała Franckiewicza) albo bezpośrednio drukarzy (Jana Karcana, Jakuba Markiewicza, Melchiora Pietkiewicza).

W książce Marka Tulia Cicero O powinnościach (Wilno 1593), przetłumaczonej przez Stanisława Kaszyckiego, a wydanej przez Jana Karca-

7 Z. Florczak, Udział regionów w ksztaltowaniu się piśmiennictwa polskiego XVI wieku..., s. 243.

8 J. Radvanas, Radivilias sive de vita et rebus... Nikolai Radivili. 
na, umieszczone są dwa utwory Kozakowicza: łacińska dedykacja Mikołajowi Naruszewiczowi, podpisana „Joannis Cosacouicij Lit.” oraz polski wiersz $\mathrm{Na}$ też ksiegi. Zwróćmy uwage na to, że poeta orientował się w przynależności gatunkowej swoich utworów, oznaczając w podtytule pierwszego: „Dodecastichon”, a w podtytule drugiego wpisując: „Epigramma Jana Kozakowicza”. Łaciński wiersz należy do poezji dedykacyjnej, polski - do poezji prefacyjnej (pełni funkcje przedmowy do czytelnika), obydwa wywodzą się z gatunku epigramatu (tak samo jak inne odmiany poezji książkowej: wiersze heroldyczne, zwroty do Zoila).

W swojej przedmowie wierszem Kozakowicz daje czytelnikowi-chrześcijaninowi radę, aby nie dbać o pożytek, lecz przypomnieć słowa pogańskich mędrców:

\section{(...) Raczey z Cyceronem}

Baw się tą Cnotą, Cnota skarbiem nie zliczonym.

A uznasz snadnie, że się lepiey bawić Cnotą,

Niżli zyskiem do sztucznych przemysłow ochotą ${ }^{9}$.

W wierszach z Nowego Testamentu (Wilno 1593) Kozakowicz potępia szlachtę za to, że wyżej od godności rycerskiej i cnót chrześcijańskich stawiła bogactwo, temat ten pojawia się w epigramatach na herby Krzysztofa Zienowicza, Mikołaja Zienowicza i Mikołaja Naruszewicza (pod wierszami znajdujemy podpis: „Jan Kozakowicz.”). Podobne zarzuty wywodzą się z tradycyjnego wyobrażenia o etyce szlacheckiej, które przetrwało w społeczeństwie do końca XIX w. ${ }^{10}$

Problemy moralno-społeczne bardziej niepokoją Jana Kozakowicza, niż wizerunki heraldyczne: poeta skarży się na upadek tradycji przodków, na niedbałość gospodarzy i chciwość lichwiarzy, natomiast swoich bohaterów-adresatów - przedstawicieli zamożnej kalwińskiej szlachty - chwali za to, że nie poskąpili pieniędzy na wydanie Nowego Testamentu. Tak więc w wierszach heraldycznych oraz dedykacyjnych Kozakowicza są obecne idee, charakterystyczne dla poezji moralno-dydaktycznej (przypomnijmy anonimowy poemat Proteus, abo Odmieniec, traktat wierszowany Macieja Stryjkowskiego Goniec Cnoty...), a nawet dla religijno-polemicznej: w dedykacji Mikołajowi Zienowiczowi poeta wyraża przekonanie, iż wydanie prawdziwego Słowa Bożego pomoże rozwiać „falszywy dym od baśni Antychrysta” (od

9 M. T. Cicero, O powinnościach wszech stanów ludzi, Wilno 1593.

10 М. Оссовская, Рыцарь и буржуа: Исследования по истории морали, Москва 1987 , c. $207-211$. 
razu przychodzi na myśl Pieśn zebrana z Zjawienia ś. Jana ... iż Papież jest prawdziwym Antykrystem z kancjonału nieświeskiego z lat 1563/1564 oraz poemat Apologetycus, to znaczy Obrona Konfederacji... z 1580 r.).

Tak więc treść epigramatów była zależna nie tylko od konwencji gatunkowej, lecz także od treści oraz charakteru całego tomu, w którym owe epigramaty były drukowane. Uchwalenie prawdziwej wiary oraz wypowiedzi antykatolickie można znaleźć również w innych wierszach Jana Kozakowicza, zamieszczonych $\mathrm{w}$ protestanckich wydaniach o charakterze religijno-oświatowym i religijno-polemicznym.

W przedruku książki Mikołaja Reja Postilla polska (Wilno 1594) były opublikowane dwa wiersze Kozakowicza: epigramat na herb Michała Franckiewicza oraz dedykacja owemu szlachcicowi, za środki którego była wydana książka (pod dedykacją stoi podpis „Jan Kozakowicz Litwin”). W epigramacie poeta opiewa zasługi wojskowe Franckiewicza dla Ojczyzny, w dedykacji natomiast dziękuje za zaspokojenie „głodu duchowego" czytelników, za obronę prawdziwej wiary i ratunek „ubogiego Zbioru" ${ }^{11}$.

Wyraźny charakter religijno-polemiczny ma prefacyjny wiersz Kozakowicza Do taskawego czytelnika, umieszczony razem z epigramatem na herb Janusza Radziwiłła w tomie Szymona Teofila Zwierciadło nabożenstwa chrzescianskiego w Polszcze (Wilno 1594). Idąc za Teofilem (Turnowskim) poeta krytykuje działalność jezuitów, przywołuje postać mitologicznego Proteusa, zdolnego do przybierania różnych obliczy, z pogardą nazywa zakonników katolickich „prawdziwymi Proteusami”, zmieniającymi tylekroć w ciągu stuleci nazwy ordenów i kolor sutanny. Kozakowicz nie szczędzi zjadliwych, a nawet brzydkich słów pod adresem jezuitów oraz papieża:

Iże takiey za czasow Apostolskich barwy

Słudzy Boży nie mieli: bo się strzegli larwy

Oney Rzymskiey, która to winem opoiona

Miała wzbudzić takowe przedziwne imiona ${ }^{12}$.

Stawiając pod ostro polemicznym wierszem swój tradycyjny podpis „Jan Kozakowicz Litwin”, poeta mógł się spodziewać szybkiej odpowiedzi z obozu przeciwników. Tego samego roku ukazuje się drukiem książka znanego teologa jezuickiego Marcina Łaszcza (pod pseudonimem: „Marcin Tworzydło") Okulary na zwierciadło nabożenstwa chrzescianskiego w Polszcze (Wilno 1594), w której znalazł się wiersz Macieja Szałajskiego Do Jana

11 M. Rej, Postilla polska, Wilno 1594.

12 [Turnowski] Sz. Theophil, Zwierciadto nabożenstwa chrzescianskiego w Polszcze, Wilno 1594 . 
Kozakowicza (niektórzy badacze przypisują autorstwo tego wiersza Marcinowi Łaszczowi $\left.{ }^{13}\right)$ :

A ty, miły Kozaczku, barzoś się poskapił,

Ześ się z Nizu do Litwy na zdobycz pokwapił:

Chcesz Mnichy po kozacku z kapice odzierać,

Nie tuta Niż, nie będziesz cudzego wydzierać.

Ja powiadam, Kozaczku, nie szarpay kapice,

Bo cię rychley niz pierwsze wyda takie lice ${ }^{14}$.

Wykorzystawszy nazwisko Kozakowicza, Szałajski skrytykował nie tylko poetę-kalwina, lecz także prawosławnych ukraińskich kozaków, którzy podczas swoich najazdów nie oszczędzali klasztorów katolickich, a szczególnie nie darzyli sympatią jezuitów. Można przypuszczać, że Kozakowicz mógł odpowiedzieć na wiersz poety-jezuity nowymi utworami. Możliwie, że właśnie jemu należy przypisać autorstwo polemicznych wierszy przeciwko Marcinowi Łaszczowi w języku lacińskim oraz polskim, których rękopisy znalazł w swoim czasie Juliusz Nowak-Dłużewski ${ }^{15}$. Nie mniej jednak poeta kontynuował publikacje swoich wierszy prefacyjnych oraz dedykacyjnych w książkach braci w wierze, propagując idee kalwińskie: w tomie Grzegorza z Żarnowca Clypeus, albo Tarcz duchowna (Wilno 1598)16 broni przed arianami boskość Chrystusa, a w kolejnym wydaniu książki Mikołaja Reja Postilla Lietuwiszka (Wilno 1600) ${ }^{17}$ nawołuje czytelnika do prawdziwej wiary.

W latach 90. XVI w. Jan Kozakowicz opublikował około piętnastu utworów w siedmiu książkach innych autorów. Jednak największą sławę przyniósł mu wydany przez Jana Karcana przekład na język polski książki Historia wojny żydowskiej Józefa Flawiusza (Wilno 1595). Później korzystając z tego tłumaczenia nieznany autor przełożył utwór na język starobiałoruski, niestety przekład ów nigdy nie był wydany ${ }^{18}$. Właśnie zasługi Kozakowicza jako

13 Z. Florczak, Udziat regionów w ksztaltowaniu się piśmiennictwa polskiego XVI wieku.., s. 193; W. R. Rzepka, A. Sajkowski, Andrzeja Rymszy Dziesięćroczna powieść wojennych spraw..., „Archiwum Literackie”, t. XVI, s. 136.

14 [Łaszcz] M. Tworzydło, Okulary na zwierciadło nabożenstwa chrzescianskiego w Polszcze, Wilno 1594.

15 J. Nowak-Dłużewski, Bibliografia staropolskiej okolicznościowej poezji politycznej (XVI-XVIII), Warszawa 1964, s. 31.

16 T. Grabowski, Literatura ariańska w Polsce 1560-1660, Kraków 1908, s. 206.

17 Z. Florczak, Udziat regionów w ksztaltowaniu się piśmiennictwa polskiego XVI wieku..., s. 242.

18 А. И. Анушкин, На заре книгопечатания в Литве, Вильнюс 1970, с. 86. 
tłumacza Historii wojny żydowskiej najczęściej podkreślają badacze kultury Białorusi i Litwy epoki renesansu ${ }^{19}$.

W związku z wydaniem utworu Flawiusza w przekładzie Kozakowicza zwróćmy uwage na dwie okoliczności. Po pierwsze, swoją pracę poeta dedykuje Krzysztofowi Zenowiczowi, któremu już wcześniej ofiarował wiersz w Nowym Testamencie (1593). Na odwrocie strony tytułowej Historii wojny żydowskiej umieszczony został herb Zenowiczów. Zabrakło jednak tradycyjnego w tym miejscu epigramatu: na pewno wszystkie siły twórcze Kozakowicz skierował tym razem na wykonanie przekładu. W części końcowej prozatorskiej dedykacji poeta wpisuje datę i miejsce swojego pobytu: „Z Mosara w dzień Nowego Lata Roku 1595" 20. W XVI w. miasteczko Mosar (koło Dzisny) było własnością Zenowiczów ${ }^{21}$, tak więc Jan Kozakowicz znajdował się widocznie na służbie owego rodu. Lecz nie tylko zależność służbowa zmusiła, aby zadedykować przekład Historii wojny żydowskiej Krzysztofowi Zenowiczowi. W dedykacji poeta wyraża wdzięczność wojewodzie brzeskiemu za pomoc w wydaniu książki i nazywa go „maecenati et artium bono cultori" ${ }^{22}$, co świadczy o znaczącym miejscu osoby Krzysztofa Zenowicza w ówczesnym życiu kulturowym Wielkiego Księstwa Litewskiego. Przypomnijmy, że Krzysztof był też jednym z bohaterów Radziwiliady... Radwana, a także sam parał się literaturą: jak podaje Ludwik Kondratowicz (Syrokomla) Zenowicz pozostawił po sobie rękopis pt. Tragedia albo początek upadku znacznego w Xięswie Litewskim, w którym dokładnie opisał dobrze znany konflikt między Radziwiłłami a Chodkiewiczami względem Zofii Słuckiej23.

Po drugie, Historia wojny żydowskiej Flawiusza w przekładzie Kozakowicza była wydana w drukarni Karcana, jednocześnie z przetłumaczonym przez Rymszę utworem Anselma Polaka Chorographia albo topographia, to iest osobliwe a okolne opisanie Ziemie Świętej (Wilno 1595). Dwaj poeci nie przypadkowo w tym samym czasie podjęli się nagle pracy tłumacza, była to raczej odpowiedź na propozycję ambitnego wydawcy (chociaż teksty

19 Ю. Лабынцаў, Пачатае Скарынам. Беларуская друкаваная літаратура эпохі Рэнесансу, Мінск 1990, с. 205; С. А. Падокшын, Роля антыцных традыциый у развічиі культуры $і$ грамадскай думкі на Беларусі ў XVI-XVII cmcm., "Беларуская літаратура", Мінск 1977, вып. 5, с. 7; M. Topolska, Czytelnik i ksiażka w Wielkim Księstwie Litewskim w dobie Renesansu i Baroku, Wrocław 1984, s. 119.

20 J. Flawiusz, Historia woyny żydowskiey, Wilno 1595.

21 Stownik geograficzny Królestwa Polskiego. t. 6, Warszawa 1885, s. 691.

22 J. Flawiusz, Historia woyny żydowskiey.

23 Л. Кондратович (Сырокомля), История польской литературье, т. 2, Москва 1862 , c. $476-477$. 
do przekładu wybrali sami, o czym piszą w przedmowach). W egzemplarzu Polskiej Biblioteki Narodowej (BN XVI 0387) przekłady dwóch przyjaciół zostały nawet umieszczone pod jedną okładką.

W wydaniach wileńskich z początku XVII w. nie znajdujemy już wierszy Jana Kozakowicza, jednak mamy wreszcie dwie jego własne książki poetyckie: Manes Danieliani (Wilno 1603) i Orzech włoski (Wilno 1603). Zwróćmy uwagę na paradoksalność kariery twórczej poety: w ciągu dwóch dziesięcioleci starannie umieszcza swoje wiersze w książkach innych autorów i raptem w jednym roku wydaje dwa własne zbiory. Oba wychodzą w drukarni Karcana, dawnego przyjaciela Kozakowicza, jak również wielu innych poetów Wielkiego Księstwa Litewskiego.

Wydany przy wsparciu Marcina Naruszewicza oraz Daniela Przystanowskiego zbiór utworów funeralnych Manes Danieliani nie był zjawiskiem wyjątkowym w ówczesnej poezji Białorusi i Litwy. Osiem polskich i cztery łacińskie wiersze, napisane z okazji nagłej śmierci kalwińskiego księdza Daniela Stefana Teolipta oraz jego bliskich krewnych (córki Zuzanny, syna Daniela, siostry Judyty), obiektywnie pokazują poziom talentu Jana Kozakowicza. Wzruszenie emocjonalne poety wywołane przez tragedię rodziny pobożnego Daniela nie znalazło swojego odbicia w wierszach, napisanych w stylu nieco dziwacznym (pierwszy tren w tryptyku Zuzanne ma nazwę zupełnie w duchu Józefa Baki: Smierć w zęby nie patrza), napełnionych tradycyjnymi chrześcijańskimi toposami o marności życia i wszechpotężnej śmierci:

\footnotetext{
Żonatyś iest, musisz się frasować o wsytko.

Nie masz żony, samemu mieszkać iakoś brzydko.

Masz dziatki - z wielką praca wychowac ie przyjdzie,

A niemasz ich - żywot twoy bez potomstwa zyidzie.

Młodyś iest - więc twa młodość śliska y niestała,

A iesliś starym - wszytka czerstwość twa ustała.

Coż daley żądać: iedno, abo się nie rodzić,

Abo sie urodziwszy, zaraz z świata zchodzić ${ }^{24}$.
}

Bardziej interesujący wydaje się być wydany w osobnym tomie Orzech włoski, publicystyczno-refleksyjny wiersz Kozakowicza zauważalnie poszerza horyzonty ówczesnej polskojęzycznej poezji Białorusi i Litwy. Wiersz odwołuje się do antycznego pierwowzoru, o czym świadczy już sam tytuł, i do czego przyznaje się poeta w dedykacji Stanisławowi Kiszce:

24 J. Cosacouitio, Manes Danieliani, Vilnae 1603, s. 24. 
Wszakże iż y ubogim kadzidłem czczą Bogi,

Przyimi ode mnie wdzięczną twarzą dar nie drogi,

Któryć przynoszę aże z Parnasu sławnego,

Orzech wyjęty na wzor z Poety Włoskiego.

Który urodziwszy się w pełnym wod Sulmonie,

Od Cesarza zasłany zmarł w Sarmackiey stronie ${ }^{25}$.

Zarówno dla polskich twórców epoki renesansu, jak i dla Litwina Kozakowicza starorzymski poeta Owidiusz jest bliski przede wszystkim tym, że swoją drogę życiową skończył w „Sarmackiej stronie” (według legendy nawet nie na Krymie, tylko na brzegach Wisły). Wykorzystawszy dla swojego utworu elegie $N u x$, Kozakowicz nie wątpi w to, że jej autorem jest „poeta z Sulmonu", choć już Aldo Manuzio (1449-1515) podważał autorstwo Owidiusza. Nie ma pewności co do tego i wśród dzisiejszych badaczy: jedni uważają, że Nux jest wczesnym utworem autora Metamorfoz, inni utrzymują, iż jest to utwór późniejszy, napisany na zesłaniu, a jeszcze inni przypisują elegie nieznanemu epigonowi Owidiusza ${ }^{26}$. W wykonaniu Jana Kozakowicza Orzech włoski jest dowolnym przekładem lacińskiego pierwowzoru, bliskim do tekstu oryginału, lekko nasycony miejscowymi realiami oraz własnymi spostrzeżeniami tłumacza (w wyniku czego tekst polski jest o 24 linijki dłuższy od łacińskiego, choć ostatnie wersy oryginału i przekładu pokrywają się).

Wiersz jest skarga drzewa orzechowego na niesprawiedliwy los: mimo że leszczyna nie wymaga żadnej opieki i przynosi wyłącznie pożytek (daje dzieciom pyszne owoce, chroni podróżnych przed słońcem), ludzie traktują ją niezwykle ostro, strącając orzechy kijami oraz kamieniami. Przyczynę swych nieszczęść pokrzywdzone drzewo widzi w tym, że jest ono prostego, a nie szlachetnego gatunku, a do tego jest niczyje, nie chroni go prawo do własności prywatnej. Narzekania leszczyny na dolę jest alegorią stanu prostego niezamożnego człowieka w społeczeństwie, a jednocześnie jest aluzją na brak szanowania własności państwowej.

Zdaniem badaczy, poprzez użalenie się drzewa orzechowego, które rośnie daleko od ogrodu, Owidiusz opłakiwał własny los wygnańca, zapomnianego przez wszystkich, a przede wszystkim - przez imperatora Augusta ${ }^{27}$. Mimo, iż Kozakowicz w dedykacji Stanisławowi Kiszce narzeka na ubóstwo, jest to raczej literacki chwyt skromności (nie mam złota, dlatego ofiaruję ci wiersz),

25 J. Kozakowicz, Orzech włoski, Wilno 1603, S. 2.

26 M. Cytowska, H. Szelest, Literatura rzymska. Okres augustowski, Warszawa 1990, s. 566 .

27 M. Cytowska, H. Szelest, Literatura rzymska, s. 566. 
niż konstatacja faktu czy prośba o wsparcie finansowe. Poeta w swoim przekładzie elegii rzymskiego klasyka kładzie akcent nie na problemy osobiste, lecz społeczne, ostrzega, że od pogwałcenia norm moralnych jest zaledwie krok do naruszenia prawa i anarchii państwowej:

(...) Wolno brać i rwać, co przy drodze leży.

Ieśliże się to godzi, więc do zamczyskiego

Wnidz sadu, muszkatelki porwi, z wiszniowego

Drzewa pozryway owoc: a wziawszy sierp krzywy,

Zaczni żać cudze zboże, człowiecze złośliwy.

Niechay taka swawola y w mieściech panuie,

Niech co uyrzy cudzego, to gwaltem zaymuie.

Pobierzcie z kramów gwałtem sukną y korzenie,

Wyłupcie z skrzyń pieniądze y drogie kamienie.

Ale się rzeczy takie nie biorą, nie wzięte

Będą, póki ustawy i prawa brzmią święte.

Y póki rządzi możny Król śliczną koroną

Y też Księstwy Wielkiemi, będzie za obroną

Iego wszystko w całości trwac. $(. . .)^{28}$

Orientacja na pierwowzór antyczny - Orzech włoski jest faktyczne parafrazą elegii $N u x$ - dyscyplinowała myśl poety oraz sprzyjała klarowności, wyrazistości stylu, czego tak brakowało jego wcześniejszym utworom. Pod tym względem Orzech włoski można śmiało nazwać szczytem twórczości Kozakowicza, który począwszy od wierszy prefacyjnych i dedykacyjnych o treści panegirycznej i religijno-polemicznej, próbując swoje siły w poezji epinicyjnej i funeralnej, doszedł do dowolnego tłumaczenia liryki o charakterze społecznym.

Po 1603 r. nie znajdujemy żadnych śladów poezji Jana Kozakowicza w drukach wileńskich, dlatego można przypuszczać, że tym właśnie bardzo owocnym dla pisarza rokiem kończy się jego skromna kariera poetycka.

Zwraca na siebie uwage refleksja białoruskiego badacza Iwana Sawierczanki, który wysunął hipotezę, że w końcu XVI - pierwszej połowie XVII wieku na Białorusi mieszkało dwóch poetów, których naukowcy błędnie uważają za jedną osobę: Jak Kozak - autor wierszy umieszczonych w książce Radivilias... Radwana oraz Jan Kozakowicz - autor wierszy w Historii wojny żydowskiej Flawiusza (w Historii nie było wierszy - S.K.) oraz tomików Manes Danieliani i Orzech włoski ${ }^{29}$. Ową hipotezę nie potwierdzają żadne dowody, jest natomiast wyraźny dowód tego, że w epoce renesansu

28 J. Kozakowicz, Orzech włoski, s. 8-9.

29 I. В. Саверчанка, Старажытная паэзія Беларусі. XVI - першая палова XVII cm., Мінск 1992, с. 41. 
był tylko jeden poeta z Kozaków, który pod dedykacjami w Radziwiliadzie podpisał się: „Jan Kozak Litwin”, później zaś podpisywał się pod swoimi utworami: „Jan Kozakowicz Litwin” lub „Joannis Cosacouicij Lit.” Dowodem tym jest litwiński (białorusko-litewski) patriotyzm poety, który przejawiał się nie tylko w treści utworów, lecz także w podpisach pod nimi: z trzydziestu znanych nam polskojęzycznych poetów Wielkiego Księstwa Litewskiego tylko Jan Kozakowicz oraz Andrzej Rymsza dodawali do swojego nazwiska przydomek „Litwin”. Można uwierzyć w to, że w tym samym czasie na Białorusi mieszkało dwóch poetów o takim samym imieniu i podobnym nazwisku, lecz w to, że właśnie ci dwaj wśród wszystkich innych poetów byli największymi patriotami swojego kraju, uwierzyć trudno.

РЭЗ Ю $\mathrm{M}$

\title{
ЗАБЫТЫ ПОЛЬСКА-БЕЛАРУСКІ ПАЭТ ЯН КАЗАКОВІЧ
}

У артыкуле разглядаецца творчасць забытага польска-беларускага паэта Яна Казаковіча (Літвіна). Паэт жыў на рубяжы 16-17 вякоў у Вільні, пісаў на польскай мове, але ў сваёй творчасці выступаў як актыўны патрыёт Вялікага Княства Літоўскага. Эпіграмы і прысвячэнні Казаковіча можна знайсці ў многіх кніжных выданнях канца 16 - пачатку 17 веку, але найбольш значным яго творам з'яўляецца паэма «Orzech włoski» («Итальянский орех») (Вільня 1603) - вольная перапрацоўка элегіi Авідыя «Nux» («Opex»).

Ключавыя словы: шматмоўная паэзія, Вялікае Княства Літойскае, Рэнессанс, традыцы, патрыятызм.

\author{
S U M M A R Y
}

\section{YAN KOZAKOVICH - FORGOTTEN POLISH AND BELARUSIAN POET}

The article is dedicated to the literary creation of a forgotten Polish and Belarusian poet Jan Kozakovich (Litvin). The poet lived at the end of 16th and the beginning of 17th century in Vilna, wrote in Polish, but in his works he is an active patriot of the Grand Duchy of Lithuania. The poet's epigrams and dedication can be found in a number of books published in the late 16th - early 17th century. However, Kozakovich's most significant work is a poem "Walnut" (Vilna 1603) - an elegy of Ovid's "The Walnut Tree", remade in freestyle.

Key words: multilingual poetry, the Grand Duchy of Lithuania, Renaissance, tradition, patriotism. 